University of Nebraska - Lincoln

DigitalCommons@University of Nebraska - Lincoln

Faculty Publications, Department of Psychology

Psychology, Department of

$10-21-2006$

\title{
The Use of Religion in Death Penalty Sentencing Trials
}

Monica Miller

University of Nevada, Reno, mkmiller@unr.edu

Brian H. Bornstein

University of Nebraska-Lincoln, bbornstein2@unl.edu

Follow this and additional works at: https://digitalcommons.unl.edu/psychfacpub

Part of the Psychiatry and Psychology Commons

Miller, Monica and Bornstein, Brian H., "The Use of Religion in Death Penalty Sentencing Trials" (2006). Faculty Publications, Department of Psychology. 176.

https://digitalcommons.unl.edu/psychfacpub/176

This Article is brought to you for free and open access by the Psychology, Department of at DigitalCommons@University of Nebraska - Lincoln. It has been accepted for inclusion in Faculty Publications, Department of Psychology by an authorized administrator of DigitalCommons@University of Nebraska - Lincoln. 
Published in Law and Human Behavior, 30 (2006), pp. 675-684. Copyright (C) American Psychology-Law Society/Division 41 of the American Psychological Association 2006. Published by Springer. Used by permission. http://www.springerlink.com/content/1573-661X/

\title{
The Use of Religion in Death Penalty Sentencing Trials
}

\author{
Monica K. Miller • Brian H. Bornstein
}

Published online October 19, 2006

\begin{abstract}
Both prosecutors and defense attorneys have presented religious appeals and testimony about a defendant's religious activities in order to influence capital jurors' sentencing. Courts that have objected to this use of religion fear that religion will improperly influence jurors' decisions and interfere with their ability to weigh aggravators and mitigators. This study investigated the effects of both prosecution and defense appeals. Prosecution appeals did not affect verdict decisions; however, use of religion by the defense affected both verdicts and the weighing of aggravators and mitigators. These results could be due to differences in perceived sincerity and remorse that are conveyed in the various appeals.
\end{abstract}

Keywords: Jury decision making, Capital punishment, Death penalty, Religion, Attorney arguments

In their adversarial role, lawyers make arguments designed to benefit their clients. One specific type of argument, a religious appeal, has been used to persuade jurors in many death penalty cases (e.g., Boyd v. French, 1998; Brown v. Payton, 2005; Carruthers v. State, 2000; Sandoval v. Calderon, 2000). Such appeals have been used in several high profile trials, such as the trial of Andrea Yates, the mother who drowned her five children in her bathtub (CNN.com, 2006). The prosecutor told the jury, "[i]t was wrong in the eyes of God and it was wrong in the eyes of the law." The jury was not convinced, however, as they ultimately spared her life.

Defense attorneys have also used religious appeals in high profile cases. Susan Smith killed her sons and invented a carjacking story to cover up the crime. Smith's attorney told the Biblical story of Jesus saving an adulterous woman from being stoned. He told jurors "He who is without sin among you, let him first cast a stone ...but no stone may be thrown unless all are thrown" (Burritt, 1995). This argument may have been effective, as the jury returned a sentence of life imprisonment despite strong public support for the death penalty (Morganthau, 1995). 
Defense attorneys also use evidence of the defendant's religiosity to persuade jurors that the defendant is not deserving of the death penalty (e.g., Boyd v. French, 1998; Brown v. Payton, 2005; Miniel v. Cockrell, 2003). In the sentencing trial of Terry Nichols, the Oklahoma City bombing accomplice, jurors deadlocked when some jurors refused to give the death penalty. These jurors felt that Nichols' recent religious conversion indicated that he could still do positive deeds while in prison (CNN.com, 2004). Because of the deadlock, Nichols was sentenced to life in prison. Thus, religious testimony played an important part in sparing Nichols' life.

These examples of Biblical appeals illustrate various ways attorneys can use religious appeals and testimony to influence jurors. Not surprisingly, the courts have had to make important rulings on the admissibility of these religious appeals and testimony (for reviews, see Blume \& Johnson, 2000; Duffy, 1997; Henson, 2001; Miller \& Bornstein, 2005; Simson \& Garvey, 2001). The result is a mishmash of rulings handed down in a variety of jurisdictions.

\section{Court decisions about the use of religion}

Although faced with similar legal questions, courts do not agree whether or not Biblical appeals are acceptable. On the other hand, testimony concerning the defendant's religiosity is generally acceptable as evidence of the defendant's character (Commonwealth v. Daniels, 1994).

\section{Court rulings on Biblical appeals}

The most restrictive courts have prohibited all religious appeals (e.g., Sandoval v. Calderon, 2000). For instance, the Pennsylvania Supreme Court ruled that "reliance ... upon the Bible ... in support of the imposition of a penalty of death is reversible error per se (Commonwealth $v$. Chambers, 1991, p. 644)." Other courts have provided guidelines for using appeals; for example, they are acceptable as long as they are not excessive (State v. Phillips, 1997), do not go beyond the character of the defendant (State v. Cauthern, 1996), do not prejudice jurors (Cunningham v. Zant, 1991), or do not prevent a fair trial (State v. Ramsey, 1993). The most lenient courts have accepted all religious appeals, stating, for example, that they are within the scope of an attorney's poetic license (Bussard v. Lockhard, 1994).

Courts barring appeals have ruled that the prosecution's use of Biblical appeals violates the Eighth Amendment prohibition on cruel and unusual punishment (see, e.g., Sandoval v. Cauldron, 2000, State v. Alston, 1995). This Amendment requires jurors to be informed of legally relevant criteria (e.g., aggravators and mitigators) when deciding whether the defendant should be put to death (Furman v. Georgia, 1972; Gregg v. Georgia, 1976). Biblical law gives "all or nothing" commands (e.g., an "eye for an eye"), which do not provide guidance or allow for consideration of mitigating factors (Carruthers v. State, 2000; Sandoval v. Calderon, 2000).

Similarly, some courts have found defense counsel's use of Biblical appeals improper because they suggest that jurors follow a law other than state law and contradict legislative death penalty statutes (Commonwealth v. Daniels, 1994; Ice v. Commonwealth, 1984). The Ice court stated "[t]he law specifies when the death penalty is appropriate, and .... the defense counsel should [not] be permitted to [suggest a] case should be decided on religious grounds (p. 676)."

\section{Court rulings on religious testimony}

In an attempt to convince the jury to spare the defendant's life, the defense can introduce evidence of the defendant's religiosity. Prison ministers, inmates, or prison employees can testify that the defendant has converted to Christianity, established a prison ministry, or 
written Christian books (e.g., Boyd v. French, 1998; Brown v. Payton, 2005; Miniel v. Cockrell, 2003). ${ }^{1}$ Religious evidence is generally allowed as evidence of a defendant's character (Commonwealth v. Daniels, 1994), consistent with the Supreme Court's ruling that defendants have a right to introduce character evidence that could be considered mitigating (Lockett v. Ohio, 1978).

\section{Effects of religious appeals}

Attorneys who use religious appeals and testimony believe they will be influential, and much research has indicated that attorney arguments are typically persuasive (see, e.g., Voss, 2005). One reason that appeals could be effective is because they represent one more argument as compared to the condition lacking appeals. Persuasion research has indicated that the sheer quantity of arguments can affect the persuasiveness of a message (see, e.g., Eagly \& Chaiken, 1993; Petty \& Cacioppo, 1984; Stasson \& Davis, 1989). Religious arguments may also be influential because they evoke jurors' emotions. Cognitive-Experiential Self-Theory (CEST) posits that an individual who experiences an emotionally significant event (e.g., a religious appeal) is likely to respond experientially (e.g., based on emotions) instead of rationally (Epstein, 1990, 1994). This makes it difficult to make logical judgments such as determining the proper sentence for a defendant. Such theories may explain why appeals are effective. In this initial study, the goal is to determine whether a variety of appeals are effective and whether they interfere with mock jurors' ability to weigh aggravators and mitigators. If these basic results are found, future studies can determine why appeals are effective.

While the use of religion in the courts has garnered the attention of the legal community (see, e.g., Miller \& Bornstein, 2005; Simons, 2004), the practice has received relatively little empirical attention. In the only study (that we know of) manipulating the use of a religious appeal, Johnson (1985) found that jurors were more likely to convict a defendant when he used evidence of his religiosity as a defense in a child abuse trial. The current study further investigates the effects of religion by determining whether various types of religious appeals and testimony influence juror decision-making in death penalty sentencing trials.

\section{Overview of experiment}

This study was designed to reveal whether religious appeals influence jurors' sentencing verdicts and prevent proper weighing of aggravating and mitigating factors. Mock jurors read a trial scenario that manipulated the number of aggravators and mitigators, whether or not the prosecutor used a Biblical appeal, and the way the defense used religion (defense attorney uses a Biblical appeal, defendant testifies that he has always been a Christian, defendant testifies that he has converted to Christianity, or no use of religion). These manipulations were chosen because they are the most commonly used in real life trials. Testing all of these appeals in one experiment allows us to compare the effectiveness of different kinds of appeals. After reading the trial scenario, participants issued a sentence of life in prison without parole or the death penalty. They also indicated their confidence in this sentencing verdict.

It was expected that the use of religion by the defense will lead to fewer death sentences as compared to a control group, with the exception of the "Always Christian" group. According to Johnson (1985), it was predicted that a defendant who testifies that he has always been a Christian will be treated more punitively than the control condition. It was also expected that

\footnotetext{
${ }^{1}$ While defendants sometimes convert to religions other than Christianity, the vast majority of cases involve a Christian conversion.
} 
religious appeals used by the prosecutor would lead to more death sentences. Based on legal concerns that religious appeals interfere with jurors' "channeled discretion," it was also predicted that both types of religious appeals would prevent jurors from properly weighing aggravators and mitigators (i.e., we predicted an interaction between the presence of a religious appeal and the strength of the evidence [more aggravators vs. more mitigators]).

\section{Method}

\section{Participants}

Participants were 265 community members from a mid-sized Midwestern community who were paid \$20 each. They were told they would be participating in a mock trial but were not told about the study's purpose (i.e., to explore the effects of religious appeals). Before reading the trial summary, participants answered a death qualification question based on the legal standard established in Wainwright $v$. Witt (1985). Sixty-four (24\%) participants who indicated that their sentiments about the death penalty were so strong that they would seriously affect their performance as a juror were excluded from the study. Eleven additional participants were eliminated because they failed to answer a large portion of the survey. Finally, six participants were eliminated because they failed to answer correctly a majority (two out of three) of the manipulation check questions. The final sample consisted of 184 participants, the majority of whom were Caucasian (90\%) and female (58\%). They ranged in age from $18-87$ years $(M=42.8, \mathrm{Mdn}=42)$ and had a variety of religious backgrounds (63\% Protestant, $15 \%$ Catholic).

Procedure and study design

After reading and signing consent forms, participants completed the death qualification questionnaire and read the trial summary and judge's instructions. The questionnaire asked participants to indicate their individual sentencing decision (life in prison without parole or a death sentence) and how certain they were in their sentence. Three manipulation check questions assessed whether participants were aware of the religious appeal/testimony manipulations. ${ }^{2}$

The design was a 2 (Case facts: High Aggravators/High Mitigators) $\times 4$ (Defense use of religion: defendant became a Christian while in prison/defendant has always been a Christian/the defense attorney makes a Biblical appeal for mercy/control condition) $\times 2$ (Prosecution use of religion: retributive Biblical appeal/control condition) between-groups factorial. Cells averaged 11.5 participants, with cell sizes ranging from eight to 16 participants.

\section{Materials}

The written trial summary described the penalty phase of a capital trial. The summary was approximately 1900 words long and contained a summary of the case facts and closing arguments. The summary was based on State v. Daniels (1994), a North Carolina case in which a man was sentenced to death for murdering his aunt. During the sentencing phase of the actual trial, both the prosecutor and defense attorney used religious appeals.

\footnotetext{
${ }^{2}$ Gender and religious differences (e.g., devotionalism, fundamentalism) were also measured. Because these measures revealed few consistent differences, these analyses are not included for brevity. Results are available from the first author.
} 
The nature of the crime was manipulated through the inclusion or exclusion of aggravators (e.g., crime was committed for pecuniary gain or was part of a series of crimes) and mitigators (e.g., defendant confessed and cooperated with authorities or is a good candidate for rehabilitation). The trial summary contained one of two fact patterns: One trial summary favored the death penalty (four aggravators and two mitigators), and the other summary favored a sentence of life in prison without the possibility of parole (two aggravators and four mitigators).

The prosecutor's use of religion was also manipulated in the trial summary. In the "Prosecutor appeal" condition, the prosecutor quoted the Bible during the closing argument (i.e., "[God] commands us to take 'an eye for an eye' and 'a tooth for a tooth.' This means that if someone kills someone, he or she also should be put to death"). In the control condition, the prosecutor did not use a Biblical appeal during his closing argument.

Finally, the use of religion by the defense was manipulated. In the "Defense Attorney Appeal" condition, the defense attorney used a Biblical appeal in closing argument (i.e., "Jesus tells us "You have heard that it has been said "an eye for an eye and a tooth for a tooth" but I say to you, do not resist an evil doer. If someone strikes you on the right cheek, turn the other also.' Jesus, the example God sent for us to follow, practiced forgiveness"). In the "Converted Christian" condition, the defendant testified that, since going to prison, he has converted to Christianity and now understands that God condemns his killing, yet is forgiving. In the "Always Christian" condition, the defendant testified that he has always been a Christian and knows that God feels what he did was wrong, but nevertheless forgives. In the control condition, neither the defendant's testimony nor the attorney's closing argument mentioned religion.

The judge's instructions and verdict form were based on those used in North Carolina. The instructions, which were approximately 2500 words long, defined each of the aggravators and mitigators and how the jurors should weigh factors in making the sentencing decision.

\section{Results}

Courts have expressed concern that religious appeals will affect jurors' sentencing verdicts. A three-way ANOVA was performed to reveal the effects of case type, prosecutorial appeals and defense use of religion on jurors' verdicts. The primary dependent variable was a "verdict confidence" score, which was created by multiplying the participant's sentencing verdict and the level of confidence in that verdict ( 7 point scale), resulting in a score ranging from -7 (highly confident in a death sentence) to +7 (highly confident in a life sentence). This measure is similar to that used in previous studies (Cook, Arndt, \& Lieberman, 2004; Huntley \& Costanzo, 2003). Tukey's HSD was used to perform post-hoc analyses. Table 1 summarizes the findings.

There was a significant main effect for case type, $F(1,161)=7.6, p<.01$. As expected, participants in the High Aggravators condition $(M=.81)$ were more punitive than those in the High Mitigators condition $(M=3.16)$. Contrary to the hypothesis, there was no main effect for prosecution appeal, $F(1,161)=.31, p>.05$. There was a main effect on verdict confidence for the type of appeal used by the defendant, $F(3,161)=3.08, p<.05$, with a significant difference between the "Converted Christian" $(M=3.4)$ condition, where participants were least punitive, and the "Defense Attorney Appeal" condition, where participants were most punitive $(M=.3, p<.05)$. There were no other significant differences among the groups, including the "Always Christian" $(M=1.8)$ and control groups $(M=1.8)$.

Another concern that courts have expressed over religious appeals is that the appeals would interfere with jurors' ability to weigh aggravators and mitigators, as required by law. Proper weighing occurs when participants favor a life sentence significantly more when they read the High Mitigators case than when they read the High Aggravators case. Alternatively, 
Table 1 Mean scores for appeals and case type on verdict confidence

\begin{tabular}{lc}
\hline Independent variable & Verdict confidence \\
\hline Prosecution appeal & \\
Prosecution Appeal & 2.15 \\
Control & 1.60 \\
Defense appeal & $1.83^{\mathrm{a}, \mathrm{b}}$ \\
Always Christian & $3.43^{\mathrm{a}}$ \\
Converted Christian & $.31^{\mathrm{b}}$ \\
Defense Appeal & $1.83^{\mathrm{a}, \mathrm{b}}$ \\
Control & $.81^{\mathrm{a}}$ \\
Case type & $3.16^{\mathrm{b}}$ \\
High Aggravators & \\
High Mitigators & \\
\hline
\end{tabular}

Note. The verdict confidence measure combines participants' verdicts (life vs, death) with their confidence judgment. It ranges from -7 to +7 , with higher (positive) scores indicating greater confidence in a life sentence. Within a variable, means with different superscripts are significantly different at $p<.05$.

if there is no significant difference between the High Aggravators and High Mitigators conditions, then it would indicate that jurors were unable to weigh the evidence properly.

There was a significant interaction between case type and defense appeal, $F(3,161)=$ 2.8, $p<.05$, which indicated that the control group and the "Converted Christian" group were able to weigh aggravators and mitigators properly. However, the "Always Christian" and "Defense Attorney Appeal" groups were not (see Fig. 1). ${ }^{3}$ For the Control group participants, the High Mitigators group $(M=4.3)$ favored a life sentence significantly more than the High aggravator group $(M=-.13 ; p<.05)$. Similarly, for the Converted Christian group, the High Mitigators group $(M=5.8)$ favored a life sentence significantly more than the High Aggravators group $(M=1.3 ; p<.05)$. This indicates that both the control and Converted Christian groups could weigh aggravators and mitigators properly. On the other hand, the Always Christian group could not; the High Mitigators participants $(M=2.5)$ did not differ from the High Aggravators participants $(M=1.4, p>.05)$. Similarly, in the Defense Attorney appeal group, the High Mitigators participants $(M=-.04)$ did not differ from the High Aggravators group $(M=.07 ; p>.05)$. Because participants in the High Aggravators condition did not differ from participants in the High Mitigators condition, these types of religious appeals interfere with proper weighing.

Looking at the interaction another way reveals that, in the High Aggravators condition, there were no differences among any of the four defense appeal conditions. This indicates that defense use of religion did not affect verdict confidence when there were several aggravating circumstances. However, when there were several mitigating circumstances (i.e., in the High Mitigators condition), "Defense Attorney Appeal" participants were more punitive than Converted Christian $(p<.001)$ and Control $(p<.05)$ participants. None of the other conditions differed significantly. Other interactions were not significant.

\footnotetext{
${ }^{3}$ Although the "Always Christian" group means are in the direction that would indicate proper weighing (High Aggravators participants were more punitive than the High Mitigators participants), the effect of evidence strength in this condition was not significant, indicating that they could not properly weigh aggravators and mitigators.
} 


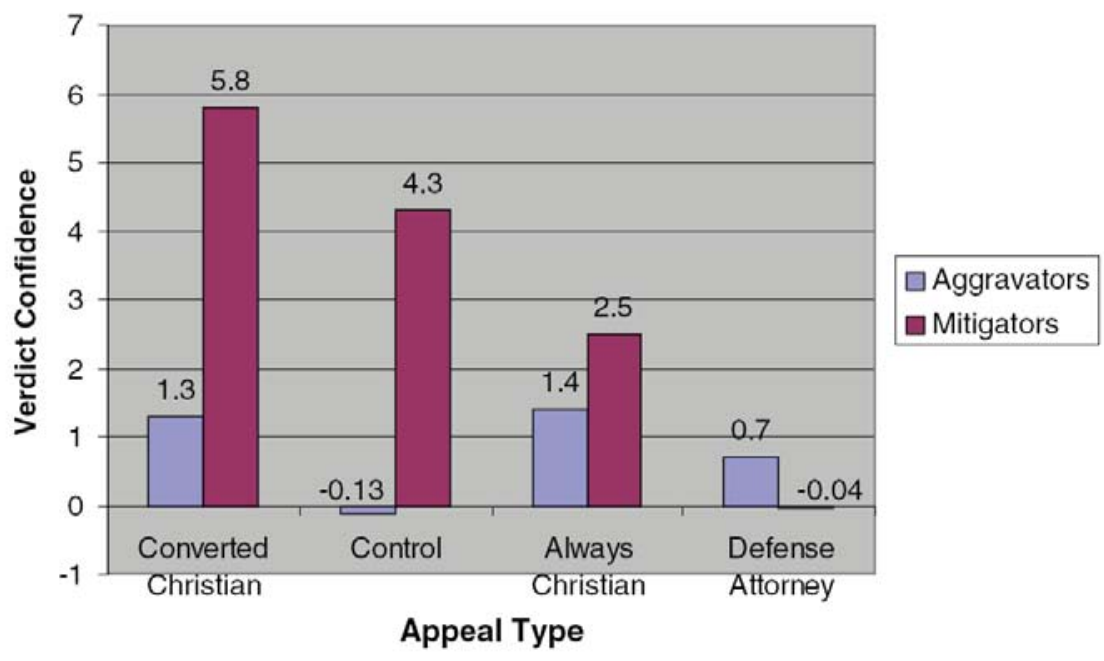

Fig. 1 Interaction between Case Type and Defense Attorney Appeal

\section{Discussion}

The use of religion has recently been discussed in various courtrooms (e.g., Brown v. Payton, 2005; Daniels v. Lee, 2003), in the legal literature (Miller \& Bornstein, 2005; Simons, 2004), and in empirical investigation (Johnson, 1985). Courts fear that appeals improperly affect sentences and interfere with the jurors' weighing of aggravating and mitigating factors (e.g., Carruthers v. State, 2000). The present research finds partial support for these concerns.

The prosecutorial Biblical appeal used in this study did not influence juror decision-making; however it should not be assumed that all prosecution appeals are harmless, as this study only tested one appeal in one trial. On the other hand, the defense attorney's use of religious appeals and evidence did affect decision-making. Mock jurors were the least punitive toward a defendant who had converted to Christianity. Participants in this study, like the Terry Nichols jurors, might have believed that the defendant has changed his ways and can still positively contribute to society. Other uses of religion (e.g., appeals from the attorney) may be less effective than testimony about a religious conversion because they are simple acts (e.g., quoting the Bible) that require little effort. Although a defendant could provide evidence of being a lifelong Christian (e.g., frequent church attendance) that would support his appeal, simply claiming to be a lifelong Christian without supporting evidence (as the defendant in the scenario did) requires little effort. In contrast, conversion requires more effort (e.g., going to church, leading a prison ministry), which might make the appeal more convincing and influential.

Another possibility is that a defendant who has converted to Christianity is treated more leniently because he is perceived to be more remorseful and sincere than defendants in other conditions. A defendant who realizes his mistake and has changed his ways is likely to be perceived as more remorseful than a defendant whose attorney quotes the Bible. Claiming to be a lifelong Christian similarly does not convey such a high level of remorse. Past research has indicated that defendants are more likely to receive forgiveness from the jury if they are remorseful (see Simons, 2004), perhaps because norms surrounding apologies lead jurors to forgive when asked (see Bennett \& Dewberry, 1994; Takaku, Weiner, \& Ohbuchi, 2001).

Additionally, a Converted Christian could be perceived more favorably than a lifelong Christian because jurors have trouble understanding how a lifetime Christian could perform 
such an evil act. Haney (2004) explains the "empathic divide" that occurs when the jurors cannot "humanize" or identify with a defendant whose life is so much different from theirs. Jurors likely have difficulty comprehending a lifetime Christian's motive for murder, making the task of humanizing him difficult. Alternatively, a converted Christian could be seen as having transitioned from an evil lifestyle that led to his behavior. This positive transition toward a more normative lifestyle could explain why converted Christians win favor in jurors' eyes.

Interestingly, mock jurors were the most punitive toward a defendant whose attorney quoted Biblical scripture prescribing mercy. Perhaps jurors felt that the appeal was a defense tactic that misused religion. Research has demonstrated that expert witnesses are viewed as less credible when they are paid (Cooper \& Neuhaus, 2000; Ivkovic \&Hans, 2003) and that paid sales assistants are seen as less credible than fellow shoppers (Harris, Davies, \& Baron, 1997). Other research indicates that the American public views attorneys negatively (Pearce, 1999). In addition, attorneys do not swear under oath, possibly making them appear even less credible. This suggests that paid advocates are seen as untrustworthy sources who will say anything to obtain the desired outcome. Much research has indicated that low-credibility sources are less persuasive than their more credible counterparts (e.g., Eagly \& Chaiken, 1993). This could explain why attorney appeals, whether by the prosecution or the defense, were not as persuasive as intended. It is especially important to note that, in the High Mitigators case, "Defense Attorney Appeal" participants were significantly more confident in a death sentence than participants in the control condition. Defense attorneys should take note that their use of Biblical appeals can backfire, especially if there are mitigating factors in the case.

This research also reveals that the fear that appeals will interfere with jurors' ability to weigh aggravators and mitigators may be a legitimate concern. Although prosecution appeals did not affect the ability to weigh aggravators and mitigators, two of the three defense appeals did. While the Control group and "Converted Christian" groups were able to weigh aggravators and mitigators properly, the "Always Christian" and "Defense Attorney Appeal" groups were uninfluenced by the strength of the evidence. It is possible that jurors experiencing these two appeals were angered that the defendant would use religion in that way. As noted above, a claim that one should be shown mercy - merely because he is a lifelong Christian or based on a Biblical quote from the attorney — may be seen as insincere. Perhaps the negative emotion triggered by the (mis)use of religion made jurors unable to weigh aggravators and mitigators.

In sum, the current study utilized realistic materials (i.e., based on real court case) and a community sample of mock jurors to test the effects of religious appeals. Although the explanations for the results are speculative, this initial study provides evidence that some types of religious appeals and testimony do improperly affect jurors' decisions. Future research should investigate these explanations and replicate the findings using different manipulations.

\section{Conclusions}

Lawyers have long used Biblical appeals and presented testimony of the defendant's religiosity, prompting some courts to express their disapproval (e.g., Sandoval v. Calderon, 2000). Although there has been an increasing amount of attention given to the effects of religion in the courtroom, little empirical research has been conducted. Results of the current study indicate that the courts could be justified in their concerns over religious appeals. Specifically, appeals by defense counsel can be detrimental to the defendant and can prevent jurors' proper weighing of aggravators and mitigators. Although additional research is needed to investigate more fully a wide range of appeals with a diversity of jurors, it would be wise for courts, lawyers and policymakers to be wary of the use of religious appeals in capital sentencing trials. 


\section{Acknowledgments}

The present research was supported by the National Science Foundation award number 0351811, the Society for the Psychological Study of Social Issues, the American Psychology-Law Society, and the University of Nebraska Law/Psychology Program. This research was presented at the 2005 conference of the American Psychology-Law Society. The authors are grateful for the research assistance of Nick Fanning and Beth Herschlag and for the helpful comments from Rich Wiener, Bob Schopp and Dick Dienstbier.

\section{References}

Bennett, M., \& Dewberry, C. (1994). “I've said I'm sorry, haven't I?" A study of the identity implications and current restraints that apologies create for their recipients. Current Psychology, 13, 10-21.

Blume, J. H., \& Johnson, S. L. (2000). Don't take his eye, don't take his tooth, and don't cast the first stone: Limiting religious arguments in capital cases. William and Mary Bill of Rights Journal, 9, 61-104.

Burritt, C. (July 30, 1995). Seeking meaning in Smith tragedy: Faith helps ease pain but "the mystery is why God allows certain things to happen." Atlanta Journal and Constitution, A 12.

CNN.com (2006, January 9). Yates: Not guilty by reason of insanity. Retrieved February 6, 2006 from http://www.cnn.com/2006/LAW/01/09/andrea.yeates.ap/index.html

CNN.com (2004, June 15). Juror: Sympathy spared Nichols. Retrieved February 6, 2006 from http://www.cnn.com/2004/LAW/06/12/nichols.react/index.html

Cook, A., Arndt, J., \& Lieberman, J. D. (2004). Firing back at the Backfire Effect: The influence of mortality salience and nullification beliefs on reactions to inadmissible evidence. Law and Human Behavior, 28, 389-410.

Cooper, J., \& Neuhaus, I. (2000). The "hired gun" effect: Assessing the effect of pay, frequency of testifying, and credentials on the perception of expert testimony. Law and Human Behavior, 24, 149-171.

Duffy, B. C. (1997). Prosecutors' use of religious arguments in the sentencing phase of capital cases. Vanderbilt Law Review, 50, 1335-1385.

Eagly, A. E., \& Chaiken, S. (1993). The Psychology of Attitudes. Fort Worth: Harcourt Brace Jovanovich.

Epstein, S. (1990). Cognitive-Experiential Self-Theory. Handbook of Personality: Theory \& Research, NY: Guilford Press.

Epstein, S. (1994). Integration of the Cognitive and the Psychodynamic Unconscious. American Psychologist, 49, 709-724.

Haney, C. (2004). Condemning the other in death penalty trials: Biographical racism, structural mitigation, and the empathic divide. DePaul Law Review, 53, 1557-1590.

Harris, K., Davies, B. J., \& Baron, S. (1997). Conversations during purchase consideration: Sales assistants and customers. The International Review of Retail, Distribution and Consumer Research, 7 , $173-190$.

Henson, M. (2001). Carruthers v. State: Thou shalt not make direct religious references in closing arguments. Mercer Law Review, 52, 731-744.

Huntley, J. E., \& Costanzo, M. (2003). Sexual harassment stories: Testing a story-mediated model of juror decision-making in civil litigation. Law and Human Behavior, 27, 29-51.

Ivkovic, S., \& Hans, V. (2003). Jurors' evaluations of expert testimony: Judging the messenger and the message. Law and Social Inquiry, 28, 441-482.

Johnson, S. D. (1985). Religion as a defense in a mock-jury trial. Journal of Social Psychology, 125, 213-220. 
Loewy, A. H. (2000). Religious neutrality and the death penalty. William and Mary Bill of Rights Journal, 9, 191-200.

Miller, M. K., \& Bornstein, B. H. (2005). Religious appeals in closing arguments: Impermissible input or benign banter? Law and Psychology Review, 29, 29-61.

Morganthau, T. (1995, August 7). Smith condemned to life, Newsweek, 19.

Pearce, R. G. (1999). Law Day 2050: Post-Professionalism, Moral Leadership, and the Law as Business Paradigm. Florida State University Law Review, 27, 9-23.

Petty, R. E., \& Cacioppo, J. T. (1984). The effects of involvement on responses to argument quantity and quality: Central and peripheral routes to persuasion. Journal of Personality and Social Psychology, 46, 69-81.

Simons, M. A. (2004). Born again on death row: Retribution, remorse and religion. Catholic Lawyer, 43, $311-337$.

Simson, G. J., \& Garvey, S. P. (2001). Knockin' on heaven's door: Rethinking the role of religion in death penalty cases. Cornell Law Review, 86, 1090-1130.

Stasson, M. F., \& Davis, J. H. (1989). The relative effects of the number of arguments, number of argument sources and number of opinion positions in group-mediated opinion change. British Journal of Social Psychology, 28, 251-262.

Takaku, S., Weiner, B., \& Ohbuchi, T. (2001). A cross-cultural examination of the effects of apology and perspective taking on forgiveness. Journal of Language and Social Psychology, 21, 144-166.

Voss, J. (2005). The Science of Persuasion: An Exploration of Advocacy and the Science Behind the Art of Persuasion in the Courtroom. Law \& Psychology Review, 29, 301-327.

\section{Cases cited}

Boyd v. French, 147 F.3d 319 (4th Cir. 1998).

Brown v. Payton, 125 S. Ct. 1432 (2005).

Bussard v. Lockhard, 32 F.3d 322 (8th Cir. 1994).

Carruthers v. State, 528 S.E.2d 217 (Ga. 2000).

Commonwealth v. Chambers, 599 A.2d 630 (Pa. 1991).

Commonwealth v. Daniels, 644 A.2d 1175 (Pa. 1994).

Cunningham v. Zant, 928 F.2d 1006 (Ga. 1991).

Furman v. Georgia, 408 U.S. 238 (1972).

Gregg v. Georgia, 428 U.S. 153 (1976).

Ice v. Commonwealth, 667 S.W.2d 671 (Ky. 1984).

Lockett v. Ohio, 438 U.S. 586 (1978).

Miniel v. Cockrell, 339 F. 3d 331 (Tex, 2003).

Sandoval v. Calderon, 241 F.3d 765 (9th Cir. 2000).

State v. Alston, 461 S.E.2d 687 (N.C. 1995).

State v. Cauthern, 1996 WL 937660 (Tenn. Crim. App. 1996).

State v. Fuller, 862 A.2d 1130 (N.J. 2004).

State v. Phillips, 940 S.W.2d 512 (Mo.1997).

State v. Ramsey, 864 S.W.2d 320 (Mo. 1993).

Wainwright v. Witt, 469 U.S. 412 (1985). 